Egyptian Journal for Aquaculture

P-ISSN: 2090-7877

E-ISSN: 2636-3984

www.braesd.org

Nasr etal., 2019; 9 (1):61-75

\title{
Effects of commercial and fish isolated gut Bacillus strains \\ supplementation on the performance of Oreochromis niloticus challenged with Aeromonas hydrophila.
}

\section{Mai E. Nasr ${ }^{1}$, Sabry M. Abd El-Motaal ${ }^{1}$, Sawsan M. El-Sheikh ${ }^{1}$, Shahira H.} Mahmoud $^{2}$

${ }^{1}$ Department of Pharmacology, Faculty of Veterinary Medicine, Zagazig University, 44511 Zagazig, Egypt.

2 chief researcher, Animal Health Research institute, 44511 Zagazig, Egypt.

Received: Dec. 19, 2018; Accepted: Jan. 24, 2019 published: Vol.9 (1):61-75; 2019

\section{Abstract}

Apparently healthy Oreochromis niloticus $(\mathrm{n}=225)$ were used to investigate the effect of commercial probiotic (B. subtilis) or fish gut isolated Bacillus strains (B. amyloliquefaciens; $7 \mathrm{H} \mathrm{N}$ and B. cereus; $29 \mathrm{H} \mathrm{N}$ ) on growth performance, immune response, some serum biochemical parameters and disease resistance against Aeromonas hydrophila infections. They were randomly assigned to four treatments with three replicates per treatment ( $45 \mathrm{fish} /$ treatment; 15 fish/replicate except control group has six replicates). The experimental fish were fed with diets supplemented with 0 (control), $1 \times 10^{6} \mathrm{CFU} \mathrm{g^{-1 }}$ fed commercial B. subtilis or gut isolated B. amyloliquefaciens $(7 \mathrm{H} \mathrm{N})$ and $B$. cereus $(29 \mathrm{H} \mathrm{N})$ for 2 months then bacterial challenge were performed at the end of the experiment. Fish fed gut isolated B. cereus $(29 \mathrm{H} \mathrm{N})$ had the highest marked $(p<0.05)$ influence on the productive performance parameters among treated groups. Furthermore, the highest levels of nitric oxide, Immunoglobulin ( $\operatorname{IgM})$ and lysozyme were found in treated groups. Infected fish fed on gut isolated $B$. cereus had a positive effect on ALT, SOD activity while creatinine and urea were marked reduction compared with other dietary treatments. It could be inferred that gut isolated Bacillus has been suggested as growth promoter, immune-stimulant in $O$. niloticus and increase protection against $A$. hydrophila infection. Among the two isolated Bacillus species, dietary supplementation with the B. cereus had the highest performance in $O$. niloticus compared with the commercial $B$. subtilis.

Keywords: Bacillus, O. niloticus, Growth, Immunity, Biochemistry, Aeromonas hydrophila. 


\section{INTRODUCTION}

Aquaculture industry is of a great importance, as a fastest growing production occupied $60 \%$ of fish production which offers cheap highquality omega-3 fatty acids enriched animal protein used for human consumption (Reda et al., 2018). The major outbreak causing severe economic losses could occur due to the exposure to microbial diseases in intensive fish aquaculture (Aly, 2013). The dealing with bacterial diseases depends mainly on the abuse of antibiotics and chemicals that negatively affect fish, human and environment, leading to the development of antibiotic resistance, disturbance to gastrointestinal microbial population and immune suppression (Harikrishman et al., 2010; Reda et al., 2013). Consequently, several probiotic "live beneficial microorganisms" is expected to become an eco-friendly potential alternative growth promoters for chemotherapeutics (Reda et al., 2018); used to control fish disease and to maintain a healthy microbial aquatic environment (Kavitha et al., 2018).

The most probiotics used in fish farms are commercial products isolated from non-fish sources; their existence could be unreliable in aquatic ecosystem (Azad and AL-Marzouk, 2008). The beneficial effects of indigenous probiotics isolated from the gut of fish as growth promoters can be exerted through improving intestinal morphology (epithelial barrier; adhesion to intestinal mucosa), providing digestive enzymes, improving gut microbiota, competing the pathogenic bacteria by inhibitory substances production and enhancing the immune response, and inducing the pro-inflammatory cytokines (Das et al., 2013; Reda and Selim, 2015; Selim and Reda, 2015).

Among the indigenous probiotics, Bacillus is aerobic, Gram positive, heat stable spore forming bacteria (Nicoholson et al., 2000; Hong $\boldsymbol{e t}$ al., 2005) and one of the most commonly used probiotics as growth promoters in aquaculture (Selim and Reda, 2015). Besides, Bacillus species has antibacterial activities, can survive in high acidic media of the stomach or high concentration of bile, able to colonize in the gut and can produce digestive enzymes (Reda et al., 2017).

Some previous study isolated and identified some indigenous probiotic strains from the gut of Clarias gariepinus (Reda et al., 2017 and Reda et al., 2018) or Labeo calbasu (Kavitha et al., 2018). As of now, the potential effects of gut isolated probiotics and applications in fish as growth promoter remain elusive. The current trial was delineated to investigate the improvement of productive performance, some immune response, serum biochemistry and disease resistance against Aeromonas. 
hydrophila infections of $O$. niloticus by commercial or gut isolated probiotics dietary supplementation.

\section{MATERIAL AND METHODS}

\section{Experimental fish:}

A total number of 225 apparently healthy $O$. niloticus with an average body weight $25.5 \pm 0.5 \mathrm{~g}$ were purchased from Central Laboratory for Aquaculture reserch, Abassa Fish Farm at Sharkia province. Fish were kept in glass aquaria filled with $90 \mathrm{~L}$ de-chlorinated fresh water. The water temperature, dissolved oxygen, $\mathrm{pH}$, ammonium and nitrite were measured and found to be $27 \pm 2^{\circ} \mathrm{C}, 5.4 \mathrm{mg} / \mathrm{l}, 7.2,0.20 \mathrm{mg} / \mathrm{l}$ and $0.02 \mathrm{mg} / \mathrm{l}$ respectively.

\section{Probiotic supplementation:}

Commercial Biomin probiotic (Natural growth promoter):- used as a commercial probiotic, each $1 \mathrm{gm}$ contains Bacillus subtilis, 1 × $10^{6} \mathrm{CFU}$ ${ }^{1}$.it is Produced by Biomin Holding $\mathrm{GmbH}$, Industries trasse 21, A-3130 Herzogenburg, Austria., imported by Dakahlia Campany Egypt. Gut isolated B. amyloliquefaciens $(7 \mathrm{H} \mathrm{N})$ and B. cereus $(29 \mathrm{H} \mathrm{N})$. Two strains of gut isolate probiotic bacteria, B. amyloliquefaciens $(7 \mathrm{H} \mathrm{N})$ and $B$. cereus $(29 \mathrm{H} \mathrm{N})$, were previously isolated from the intestine of $C$. gariepinus, were identified by $16 \mathrm{~S}$ rRNA gene sequencing and maintained in tryptic soya agar slopes at $4^{\circ} \mathrm{C}$. Different sequences of $16 \mathrm{~S}$ rRNA were submitted to the Gene bank database and accession numbers were KX015882 and KX015885, respectively were kindly supported by d.rasha reda fish disease department (Reda et al., 2018). The previously isolated Bacillus species were screened for activity against fish pathogens, safety, resistance to acidic $\mathrm{pH}$ and tolerance, antibiotic susceptibility, extra-cellular amylase and protease production (Reda $\boldsymbol{e t}$ al., 2018). One $\mathrm{mL}$ of the culture $(24 \mathrm{~h})$ of each isolate was centrifuged at $3000 \mathrm{rpm}$ for $30 \mathrm{~min}$ at $4^{\circ} \mathrm{C}$. The pellets were washed by sterilized saline then were centrifuged at $3000 \mathrm{rpm}$ for $5 \mathrm{~min}$. The final concentration of each probiotic isolate was adjusted to $10^{10} \mathrm{CFU} / \mathrm{ml}$ in saline using McFarland standard tube.

\section{Feeding and experimental design:}

The diets were prepared at Fish Research Center, Faculty of Veterinary medicine, Zagazig University, Egypt. The fish were randomly assigned into 4 experimental treatments with 3 replicates/treatment (45 fish/ treatment; 15 fish/replicate except control group has six replicates). Experimental treatments supplemented with probiotics in diets at rate 0 (control treatment), $1 \times 10^{6} \mathrm{CFU} \mathrm{g}^{-1}$ feed commercial B. subtilis (treatment 2), $1 \mathrm{x}$ 
$10^{6} \mathrm{CFU} \mathrm{g}^{-1}$ feed gut isolated B. amyloliquefaciens $(7 \mathrm{H} \mathrm{N})$ (treatment 3) and $1 \times 10^{6} \mathrm{CFU} \mathrm{g}{ }^{-1}$ feed gut isolated B. cereus $(29 \mathrm{H} \mathrm{N})$ (treatment 4$)$ for 2 months. It was prepared by mechanical mixing probiotics with the basal diet ingredient table $1 \& 2$, and then finally pelleted. The pellets were dried at room temperature $\left(26^{\circ} \mathrm{C}\right.$ for $\left.48 \mathrm{~h}\right)$ and stored in a refrigerator at $4{ }^{\circ} \mathrm{C}$ until use. It contained $(2940 \mathrm{kcal} / \mathrm{kg} \mathrm{ME}$ and $30.80 \% \mathrm{CP})$ in the form of dry pellets and prepared to fulfil the nutrient needs of Nile tilapia (NRC, 1993). Feedstuffs used in diets preparation were examined according to A.O.A.C. (2002). All fish were provided with their diets at a level of $3 \%$ of body weight three times daily. The feeding period lasted for 2 months and the growth performance indicators were measured.

At the end of feeding period, the control group was subdivided into 2 equal groups (negative (G1) and positive infected (G2) control group) so trial become 5 equal groups, each group contain 45 fish and make challenge test.

\section{Challenge test:}

After 60 days of feeding trial, all groups except negative control group (G1) were challenged with intraperitoneal injection of $0.1 \mathrm{ml}$ of

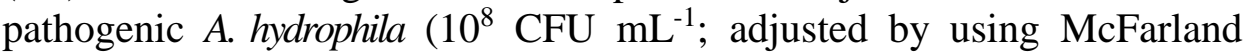
standard tubes) previously isolated from moribund fish and confirmed to be pathogenic (Talpur and Ikhwanuddin, 2012).

Challenged fish were observed for clinical signs and mortality for 14 days. Any dead fish were subjected immediately to post-mortem examination and routine bacteriological examinations.

\section{Sampling:}

Blood samples were collected at 3 days post-challenge for evaluation of some immunological parameters and assessment of some biochemical parameters. Blood samples were taken without EDTA and were centrifuged at $3000 \mathrm{rpm}$ for 15 minutes for serum separation.

\section{Growth Performance Parameters:}

The fish were weighed at the beginning and after 2 months feeding. Average body weight (BW), Body gain (BWG), body gain percent (BG $\%$ ), specific growth rate (SGR) and feed conversion ratio (FCR) were determined according to (Windell $\boldsymbol{e t}$ al., 1978; Merrifield $\boldsymbol{e t}$ al., 2011, Jauncey and Ross, 1982; Zehra and Khan, 2011; Siddiqui et al., 1988, respectively). 
Determination of some immunological and biochemical parameters:

Nitric oxide (NO) level was detected as the method described by Rajaraman $\boldsymbol{e t}$ al. (1998). Lysozyme activity was detected according to Parry et al. (1965). Immunoglobulin (IgM) was measured by an ELISA according to Fuda $\boldsymbol{e t}$ al. (1991). Alanine aminotransferase (ALT) was assessed as described by Reitman and Frankel (1957). Serum creatinine was assessed by using the method of Henry (1974). Serum superoxide dismutase activity was determined using the method of (Sheikh $\boldsymbol{e t}$ al., 2009).

\section{Statistical analysis:}

Data was analyzed by one way ANOVA using computerized SPSS (version 23; IBM Corp., Armonk, NY) statistical software package; LSD (Least significance difference) test was used to separate significance means (Snedecor and Cochran, 1982). Alternations among group means were compared using Duncan's multiple range tests (Duncan, 1995). Statement of statistical significance taken as $p<0.05$.

\section{RESULTS AND DISCUSSION}

In the present study, the feeding commercial $B$. subtilis, gut isolated $B$. amyloliquefaciens and gut isolated $B$. cereus supplemented diets for 60 days had a marked $(p<0.05)$ influence on total final BW, body gain, body gain $\%$, specific growth rate $\%$ and a marked $(p<0.05)$ improve or decrease in FCR of $O$. niloticus. Fish fed gut isolated B. cereus $(29 \mathrm{H} \mathrm{N})$ had the highest marked $(p<0.05)$ influence on the productive performance parameters among treated groups Table 3 . This strong beneficial effect on productive performance for commercial and gut isolated probiotics could be attributed to promoting nutrients digestibility and absorption; enhancing the synthesis of vitamins, cofactors and digestive enzymes; the depression of pathogenic microbial agents that hinder growth; detoxify the harmful substance in feed or increase the intestinal villus heights (Reda and Selim, 2015; Reda et al., 2018). In the present investigation, dietary inclusion of commercial and gut isolated probiotics had a strong effect on the growth performance of fish. These results agreed with some reports showing that the fish productive performance was positively affected by dietary supplementation of commercial Bacillus probiotics (Reda and Selim, 2015) or gut isolated Bacillus probiotics (Reda et al., 2018). In contrast to our findings, growth parameters for fish fed commercial Bacillus probiotics (Zhou et al., 2010) or gut isolated Bacillus probiotics (Albuquerque et al., 2013) was not significantly affected. 
Table 3: Effect of the dietary commercial and gut isolated probiotics supplementation for 60 days on growth performance parameters of $O$. niloticus.

\begin{tabular}{lcccc}
\hline \multirow{2}{*}{ Parameters } & \multicolumn{4}{c}{ Experimental groups } \\
\cline { 2 - 5 } & G1 & G2 & G3 & G4 \\
\hline \multirow{2}{*}{ Initial BW (g) } & 25.80 & 26.23 & 26.27 & 25.63 \\
& $\pm 0.06^{\mathrm{a}}$ & $\pm 0.35^{\mathrm{a}}$ & $\pm 0.27^{\mathrm{a}}$ & $\pm 0.09^{\mathrm{a}}$ \\
Final BW (g) & 35.58 & 39.11 & 39.18 & 40.80 \\
& $\pm 0.39^{\mathrm{c}}$ & $\pm 0.32^{\mathrm{b}}$ & $\pm 0.77^{\mathrm{b}}$ & $\pm 0.12^{\mathrm{a}}$ \\
Body gain (g) & 9.78 & 12.88 & 12.91 & 15.17 \\
& $\pm 0.33^{\mathrm{c}}$ & $\pm 0.57^{\mathrm{b}}$ & $\pm 0.75^{\mathrm{b}}$ & $\pm 0.03^{\mathrm{a}}$ \\
Body gain (\%) & 37.90 & 49.10 & 49.14 & 59.18 \\
Specific growth rate & $\pm 1.20^{\mathrm{c}}$ & $\pm 2.73^{\mathrm{b}}$ & $\pm 2.94^{\mathrm{b}}$ & $\pm 0.14^{\mathrm{a}}$ \\
(\%) & 0.53 & 0.66 & 0.67 & 0.77 \\
Feed intake (g) & $23.01^{\mathrm{c}}$ & $\pm 0.03^{\mathrm{b}}$ & $\pm 0.03^{\mathrm{b}}$ & $\pm 0.01^{\mathrm{a}}$ \\
& $\pm 1.03^{\mathrm{a}}$ & 22.19 & 21.84 & 21.89 \\
Feed conversion & 2.39 & $1.76^{\mathrm{a}}$ & $\pm 0.44^{\mathrm{a}}$ & $\pm 0.46^{\mathrm{a}}$ \\
ratio & $\pm 0.03^{\mathrm{a}}$ & $\pm 0.09^{\mathrm{b}}$ & $\pm 0.01^{\mathrm{b}}$ & $\pm 0.11^{\mathrm{c}}$ \\
\hline
\end{tabular}

Values are represented as the mean \pm SE. Different superscript letters within-row denote significant difference $(p<0.05)$. G1: was fed a basal diet, G2: was fed a basal diet supplemented with commercial $B$. subtilis, $\left(6 \mathrm{H} \mathrm{N} ; 1 \times 10^{6} \mathrm{CFU} \mathrm{g}^{-1}\right.$ feed), G3: was fed a basal diet supplemented with gut isolated $B$. amyloliquefaciens, $\left(7 \mathrm{H} \mathrm{N} ; 1 \times 10^{6} \mathrm{CFU} \mathrm{g}^{-1}\right.$ feed), G4: was fed a basal diet supplemented with gut isolated B. cereus, $(28 \mathrm{H} \mathrm{N} ; 1 \mathrm{x}$ $10^{6} \mathrm{CFU} \mathrm{g}^{-1}$ feed).

The non-specific immune system of fish is considered to be the first line of defense against invading pathogens. Nitric oxide, IgM and lysozyme are important indices of non-specific immunity in fishes. Our results revealed that the highest levels of nitric oxide, $\operatorname{IgM}$ and lysozyme were found in treated groups which fed either commercial or gut isolated probiotics supplemented diets compared with control table ,4. Fish diet supplemented with gut isolated B. cereus $(29 \mathrm{H} \mathrm{N})$ had the highest marked $(p<0.05)$ influence on the non-specific immune system among treated groups. Similarly, the administration of probiotics can improve immunity and protect against several pathogens in many fishes (Gupta $e t$ al., 2014). In contrast to our findings, immune response for fish fed Bacillus probiotics (Heo et al., 2013) was not significantly affected. The greater immune response in probiotic-supplemented diets might be due to 
greater production of antimicrobial substances by probiotic bacteria or due to the natural immune components of the fish themselves, including protective proteins (globulin), lysozyme, nitric oxide, immunoglobulins, activation of proteins of the complement system and cytokines (Reda and Selim, 2015).

Nitric oxide (NO) is serum potent bactericidal reactive oxygen that is produced primarily by macrophages following stimulation with a variety of agents, such as microbial components and cytokines (Campos-Perez et al., 2000) and showed a variety of biological functions as microbicidal and tumoricidal activity, and a range of immunopathologies (Saeij et al., 2002). In present study results, the highest marked levels of nitric oxide were noticed in infected commercial (B. subtilis) or infected gut isolated probiotics (B. amyloliquefaciens and B. cereus) supplemented diets which indicate that the non-specific immune system was enhanced in the fish. Also, in accordance with our results, serum nitric oxide reported from $A$. hydrophila infected fish supplemented with commercial Bacillus probiotics (Selim and Reda, 2015; Liu et al., 2017) or gut isolated Bacillus probiotics (Reda et al., 2018) was significantly affected.

Table 4: Effect of the dietary commercial and gut isolated probiotics supplementation on some immunological parameters of A. hydrophila infected $O$. niloticus.

\begin{tabular}{lccccc}
\hline \multirow{2}{*}{ Parameters } & \multicolumn{5}{c}{ Experimental groups } \\
\cline { 2 - 6 } & $\mathbf{G 1}$ & $\mathbf{G 2}$ & $\mathbf{G 3}$ & $\mathbf{G 4}$ & $\mathbf{G 5}$ \\
\hline Nitric oxide & $\mathbf{2 6 . 2 1}$ & $\mathbf{2 1 . 1 0}$ & $\mathbf{3 8 . 0 7}$ & $\mathbf{4 0 . 4 3}$ & $\mathbf{4 1 . 9 3}$ \\
$(\boldsymbol{\mu g} / \mathbf{m l})$ & $\pm 0.93^{\mathrm{c}}$ & $\pm 0.51^{\mathrm{d}}$ & $\pm 1.10^{\mathrm{b}}$ & $\pm 0.43^{\mathrm{ab}}$ & $\pm 1.18^{\mathrm{a}}$ \\
IgM $(\boldsymbol{\mu g} / \mathbf{m l})$ & $\mathbf{0 . 3 0}$ & $\mathbf{0 . 2 0}$ & $\mathbf{0 . 5 8}$ & $\mathbf{0 . 7 1}$ & $\mathbf{0 . 7 4}$ \\
& $\pm 0.02^{\mathrm{c}}$ & $\pm 0.02^{\mathrm{d}}$ & $\pm 0.02^{\mathrm{b}}$ & $\pm 0.004^{\mathrm{a}}$ & $\pm 0.02^{\mathrm{a}}$ \\
Lyzozyme $(\boldsymbol{\mu g}$ & $\mathbf{0 . 2 8}$ & $\mathbf{0 . 2 2}$ & $\mathbf{0 . 4 5}$ & $\mathbf{0 . 4 9}$ & $\mathbf{0 . 5 6}$ \\
/ml) & $\pm 0.01^{\mathrm{c}}$ & $\pm 0.01^{\mathrm{d}}$ & $\pm 0.0 .02^{\mathrm{b}}$ & $\pm 0.01^{\mathrm{b}}$ & $\pm 0.02^{\mathrm{a}}$ \\
\hline
\end{tabular}

Values are represented as the mean \pm SE. Different superscript letters within-row denote significant difference $(p<0.05)$. G1: was fed a basal diet, G2: was fed a basal diet and infected with $A$. hydrophila bacteria, G3: was fed a basal diet supplemented with commercial B. subtilis $\left(1 \times 10^{6} \mathrm{CFU} \mathrm{g}{ }^{-1}\right.$ feed $)$ and infected with A. hydrophila bacteria, G4: was fed a basal diet supplemented with gut isolated $B$. amyloliquefaciens and infected with $A$. hydrophila bacteria, $\left(7 \mathrm{H} \mathrm{N} ; 1 \times 10^{6} \mathrm{CFU} \mathrm{\textrm {g } ^ { - 1 }}\right.$ feed), G5: was fed a basal diet supplemented with gut isolated B. cereus, $\left(28 \mathrm{H} \mathrm{N} ; 1 \times 10^{6} \mathrm{CFU} \mathrm{\textrm {g } ^ { - 1 }}\right.$ feed) and infected with A. hydrophila bacteria. 
IgM is the main soluble forms immunoglobulin present in fish (Watts et al., 2001). The soluble Immunoglobulin (IgM) forms which are present in the blood and other fluids play a role as an immune effector molecule (Ross et al., 1998). Our study showed marked increasing serum IgM of $A$. hydrophila infected fish supplemented with commercial ( $B$. subtilis) or gut isolated probiotics (B. amyloliquefaciens and B. cereus) supplemented diets when compared to control. On similar ground of our results, serum levels of IgM was significantly improved either in fish fed diets supplemented with commercial Bacillus probiotics (Kamgar et al., 2013; Selim and Reda, 2015) or gut isolated Bacillus probiotics (Reda et al., 2018).

The serum lysozyme activity is considered as a defence barrier against bacterial pathogens thus resulting in the reduction of disease (Misra $\boldsymbol{e t}$ al., 2006). Lysozyme is an indispensable bactericidal cationic enzyme that hydrolyzes the peptidoglycan layers of bacterial cell walls by splitting glycosidic bonds between $\mathrm{N}$-acetylmuramic acid and Nacetylglucosamine and is increased in the sera of fish during infection with various variable microorganisms (Alexander and Ingram, 1992). Lysozyme is produced by leucocytes, mainly neutrophils and macrophages, and reacts against gram-positive and some gram-negative bacteria (Saurabh and Sahoo, 2008). The present trial revealed a marked elevation in serum lysozyme activity of $A$. hydrophila infected fish supplemented with commercial $B$. subtilis; gut isolated $B$. amyloliquefaciens and $B$. cereus supplemented diets when compared to control. Probiotics can cause increase the IgM, lysozyme and produce different cytokines in the fish so stimulate the immunity system of the fish's stomach through increasing the cells of the immunoglobulin and acidophil granulocyte (Hoseinfar and Pooramini, 2007). The process of the production of the immunoglobulins in the fish is the occurrence of a collection of the reactions among the antigen presenting cells, the activated $\mathrm{T}$ helper cells and interleukins which stimulates the $\mathrm{B}$ lymphocytes which produce the plasma cells as a result of the stimulation which are able to secrete the immunoglobulin (Tavakoli and Akhlaghi, 2009). Our result agrees with some reports stated that the serum lysozyme activity of $A$. hydrophila infected fish was positively affected by dietary supplementation commercial Bacillus probiotics (Kamgar et al., 2013; Selim and Reda, 2015) or gut isolated Bacillus probiotics (Reda et al., 2018). In contrast to our results, serum lysozyme activity for fish supplemented with commercial probiotics was significantly decreased (Das et al., 2013) or was not significantly affected (Cha et al., 2013). 
In the present study, there were positive differences between dietary treatments and control in resistance to diseases table5. This may be returned to the ability of Bacillus spore to survive, transit cross gastrointestinal tract (GIT), resist GIT environments, germinate and vegetate with heterologous antigen expression before being excreted (Duc et al., 2003). These results agreed with some studies showing that the survival rate of $A$. hydrophila infected fish was marked influence by dietary supplementation of commercial Bacillus probiotics (Das et al., 2013) or gut isolated Bacillus probiotics (Liu et al., 2017; Reda et al., 2018). In contrast to present findings, survival rate for fish fed Bacillus probiotics (Cerezuela $\boldsymbol{e t}$ al., 2012) was not significantly affected.

Serum ALT, creatinine and urea are considered important parameters to evaluate unconventional feedstuffs and new feed additives for its proper additional level (Diaz et al., 2003). The present results are showing significant $(p<0.05)$ reduction for serum ALT value between infected treated fish groups, table 5. Infected fish fed on gut isolated $B$. cereus had a positive effect on ALT. This reduction in probiotics groups might be attributed to their roles in improvement of liver histology. In line with our findings, the serum ALT activity of $A$. hydrophila infected fish was a significant decrease by dietary inclusion of Bacillus probiotics (Kamgar et al., 2013). While in our study, there was a significant increase in ALT level was noticed in infected control group. Elevated levels in ALT value may indicate degeneration, necrosis, and destruction of the liver and kidney due to cellular damage.

Creatinine and urea in fish can be used as a rough index of the glomerular filtration rate (Hernandez and Coulson, 1967) and urea is produced by liver and excreted by kidney (Stoskoph, 1993). In our trial, creatinine and urea of $A$. hydrophila infected fish were marked reduction by dietary supplementation of commercial or gut isolated probiotic bacteria. The reduction of serum urea in probiotics groups might be attributed to their roles in improvement of kidney histology. These results agreed with some studies showing that the creatinine and urea of $A$. hydrophila infected fish was marked influence by dietary supplementation of Bacillus probiotics bacteria (Kamgar et al., 2013).

In our study, there were positive differences between dietary treatments and control in serum SOD activity. These results agreed with some studies showing that the serum SOD activity for A. hydrophila infected fish was marked increase by dietary supplementation of commercial Bacillus probiotics (Cha et al., 2013) or gut isolated Bacillus probiotics (Reda et al., 2018). In contrast to our findings, serum SOD 
activity for A. hydrophila infected fish fed Bacillus probiotics (Thy et al., 2017) was not significantly affected.

Table 5: Effect of the dietary commercial and gut isolated probiotics supplementation on survival rate, serum levels of ALT, creatinine, urea and SOD of $A$. hydrophila infected $O$. niloticus.

\begin{tabular}{lccccc}
\hline \multirow{2}{*}{ Parameters } & \multicolumn{5}{c}{ Experimental groups } \\
\cline { 2 - 6 } & G1 & G2 & G3 & G4 & G5 \\
\hline Survival rate & 77.30 & 65.20 & 94.60 & 95.70 & 96.80 \\
$($ \%) & & & & & \\
ALT (IU/L) & $\mathbf{4 3 . 9 4}$ & $\mathbf{4 5 . 9 1}$ & $\mathbf{3 6 . 8 9}$ & $\mathbf{3 5 . 9 0}$ & $\mathbf{3 3 . 9 0}$ \\
& $\pm 0.51^{\mathrm{b}}$ & $\pm 0.47^{\mathrm{a}}$ & $\pm 0.50^{\mathrm{c}}$ & $\pm 0.49^{\mathrm{c}}$ & $\pm 0.48^{\mathrm{d}}$ \\
Creatinine & $\mathbf{0 . 4 4}$ & $\mathbf{0 . 5 1}$ & $\mathbf{0 . 3 7}$ & $\mathbf{0 . 3 2}$ & $\mathbf{0 . 3 1}$ \\
(mg/ dl) & $\pm 0.01^{\mathrm{b}}$ & $\pm 0.01^{\mathrm{a}}$ & $\pm 0.0 .02^{\mathrm{c}}$ & $\pm 0.02^{\mathrm{d}}$ & $\pm 0.02^{\mathrm{d}}$ \\
Urea (mg/ dl) & $\mathbf{1 7 . 6 9}$ & $\mathbf{2 6 . 7 6}$ & $\mathbf{1 4 . 3 3}$ & $\mathbf{1 3 . 5 3}$ & $\mathbf{1 2 . 1 2}$ \\
& $\pm 0.38^{\mathrm{b}}$ & $\pm 0.83^{\mathrm{a}}$ & $\pm 0.61^{\mathrm{c}}$ & $\pm 0.20^{\mathrm{cd}}$ & $\pm 0.41^{\mathrm{d}}$ \\
SOD (ug/ml) & $\mathbf{0 . 0 8}$ & $\mathbf{0 . 0 4}$ & $\mathbf{0 . 2 0}$ & $\mathbf{0 . 2 3}$ & $\mathbf{0 . 3 2}$ \\
& $\pm 0.01^{\mathrm{c}}$ & $\pm 0.01^{\mathrm{d}}$ & $\pm 0.0 .02^{\mathrm{b}}$ & $\pm 0.02^{\mathrm{b}}$ & $\pm 0.02^{\mathrm{a}}$ \\
\hline
\end{tabular}

Values are represented as the mean \pm SE. Different superscript letters within-row denote significant difference $(p<0.05)$. G1: was fed a basal diet, G2: was fed a basal diet and infected with $A$. hydrophila bacteria, G3: was fed a basal diet supplemented with commercial B. subtilis (1 x $10^{6} \mathrm{CFU} \mathrm{g}^{-1}$ feed) and infected with A. hydrophila bacteria, G4: was fed a basal diet supplemented with gut isolated $B$. amyloliquefaciens and infected with $A$. hydrophila bacteria, $\left(7 \mathrm{H} \mathrm{N} ; 1 \times 10^{6} \mathrm{CFU} \mathrm{g}{ }^{-1}\right.$ feed), G5: was fed a basal diet supplemented with gut isolated B. cereus, $\left(28 \mathrm{H} \mathrm{N} ; 1 \times 10^{6} \mathrm{CFU} \mathrm{\textrm {g } ^ { - 1 }}\right.$ feed) and infected with $A$. hydrophila bacteria.

\section{CONCLUSION}

It could be concluded that addition of commercially or gut isolated prepared Bacillus species to Oreochromus niloticus diets in a dose of $1 \times 10^{10} \mathrm{CFU} / \mathrm{g}$ had significantly additive benefit in improved growth performance, immune status, serum antioxidants and functions of liver and kidney. The supplementation of Bacillus probiotics increased the survivability percentages after inoculation of fish with A. hydrophila. Based on our results, it seems that the gut isolated freshly added probiotic; B. cereus had better performance than commercially prepared $B$. substilis. Finally, keeping in view the ecofriendly nature, other beneficial effects of gut isolated freshly added probiotic; it can effectively 
provide an alternative to the use of antibiotic growth promoter in the aquaculture industry.

\section{REFERENCES}

Albuquerque, D.M., Marengoni, N.G., Boscolo, W.R., Ribeiro, R.P., Mahl, I. and Moura, M.C. (2013): Probióticos em dietas para tilápia do Nilo durante a reversão sexual. Cienc. Rural, 43(8): 1503-1508

Alexander, J.B. and Ingram, G.A. (1992): Noncellular nonspecific defence mechanisms of fish. Annu Rev Fish Dis., 2: 249-279.

Aly, S.M. (2013): A Review of fish diseases in the Egyptian aquaculture sector: Working Report.

AOAC, (2002): Association official analytical chemists. Official Methods of Analysis. Gaithersburg, MD, U.S.A. Chapt. 4, pp 20 - 27.

Azad, I. and AL-Marzouk, A. (2008): Autochthonous aquaculture probiotics-A critical analysis, Res. J. Biotechnol., 171-177.

Campos-Perez, J.J., Ward, M., Grabowski, P.S., Ellis, A.E. and Secombes, C.J. (2000): The gills are an important site of iNOS expression in rainbow trout Oncorhynchus mykiss after challenge with the Gram-positive pathogen Renibacterium salmoninarum. Immunology, 99: 153-161.

Casula, G. and Cutting, S.M. (2002): Bacillus probiotics: spore germination in the gastrointestinal tract. Appl. Environ. Microbiol. 68 (2002) 2344-2352.

Cerezuela, R., Guardiola, F.A., González, P., Meseguer, J. and Esteban, M.Á. (2012): Effects of dietary Bacillus subtilis, Tetraselmis chuii, and Phaeodactylum tricornutum, singularly or in combination, on the immune response and disease resistance of sea bream (Sparus aurata L.). Fish Shellfish Immunol., 33: 342-349.

Cha, J.H., Rahimnejad, S., Yang, S.Y., Kim, K.W. and Lee, K.J. (2013): Evaluations of Bacillus spp. as dietary additives on growth performance, innate immunity and disease resistance of olive flounder (Paralichthys olivaceus) against Streptococcus iniae and as water additives. Aquaculture, 402: 50-57.

Das, A., Nakhro, K., Chowdhury, S. and Kamilya, D. (2013): Effects of potential probiotic Bacillus amyloliquifaciens FPTB16 on systemic and cutaneous mucosal immune responses and disease resistance of catla (Catla catla), Fish Shellfish Immunol., 35: 1547-1553.

Diaz, G.J., Roldan, I.P., Cortez, A. (2003): Intoxication of Crotalaria pallida seeds to growing broiler chicks. Vet Hum Toxicol, 45: 187-189. 
Duc, L.H., Hong, H.A. and Cutting, S.M. (2003): Germination of the spore in the gastrointestinal tract provides a novel route for heterologous antigen delivery. Vaccine, 21: 4215-4224.

Duncan, D.B. (1995): Multiple range and multiple F-tests. Biometrics, 11: 1-42.

Fuda, H., K., Sayano, F., Yamaji and Haraj (1991): Comp Brioche, Physiol., 99: 637-643.

Gupta, A., Gupta, P. and Dhawan, A. (2014): Dietary supplementation of probiotics affects growth, immune response and disease resistance of Cyprinus carpio fry. Fish Shellfish Immunol., 41: 113-119.

Harikrishman, R., Balasundaram, C. and Heo, M.S. (2010): Lactobacillus BK sakei 19 enriched diets enhance the immunity status and disease resistance to streptococcosis infection in kelp grouper, Epinephelus bruneus. Fish Shellfish Immunol., 29: 1037-1043.

He, S., Liu, W., Zhou, Z., Mao, W., Ren, P. and Marubashi, T. et al., (2011): Evaluation of probiotic strain Bacillus subtilis C-3102 as a feed supplement for koi carp (Cyprinus carpio). J Aquac. Res. Dev., S1: 005.

Henry, T. J. (1974): Determination of serum creatinine. Clin. Chem. Principles and techniques. $2^{\text {nd }}$ Ed. Harper and Row Publishers. New York.

Heo, W.S., Kim, Y.R., Kim, E.Y., Bai, S.C. and Kong, I.S. (2013): Effects of dietary probiotic, Lactococcus lactis subsp. lactis I2, supplementation on the growth and immune response of olive flounder (Paralichthys olivaceus). Aquaculture 376: 20-24.

. Biochem. Physiol., 23: 775-784.

Hong, H.A., Duc, L.H. and Cutting, S.M. (2005): FEMS Microbiol. Rev., 29 (4): 813-835.

Hoseinfar, S. H. and Pooramini, M. (2007): Application of probiotics and prebiotic in aquaculture. Green Wave Publication. Iran, Tehran.

Jauncey, K. and Ross, B. (1982): A guide to tilapia feeds and feeding. University of Stirling, Stirling, UK.

Kamgar, M., Pourgholam, R., Ghiasi, M. and Ghane, M. (2013): Studies on Bacillus subtilis, as Potential Probiotics, on the Biochemical Parameters of Rainbow trout, Oncorhynchus mykiss (Walbaum) to Challenge Infections. Advanced Studies in Biology, 5(1): 37-50. 
Kavitha, M., Raja M. and Perumal P. (2018): Evaluation of probiotic potential of Bacillus spp. isolated from the digestive tract of freshwater fish Labeo calbasu (Hamilton, 1822). Aquaculture Reports, 1 : 59-69.

Liu, H., Wang, S., Cai, Y., Guo, X., Cao, Z., Zhang, Y., Liu, S., Yuan, W., Zhu, W., Zheng, Y., Xie, Z., Guo, W. and Zhou, Y. (2017): Dietary administration of Bacillus subtilis HAINUP40 enhances growth, digestive enzyme activities, innate immune responses and disease resistance of tilapia, Oreochromis niloticus. Fish and Shellfish Immunology, 18(82): 296-303.

Mello, H.D., Moraes, J.R.E., Niza, I.G., Moraes, F.R.D., Ozório, R.O.A. Shimada, M.T., Engracia , J.R. and Claudiano, G.S. (2013): Efeitos benéficos de probióticos no intestino de juvenis de Tilápia-do-Nilo. Pesq. Vet. Brasil., 33: 724-730.

Merrifield, D. L., Harper G. M., Mustafa, S., Carnevali, O., Picchietti, S. and Davies, S. J. (2011): Effect of dietary alginic acid on juvenile tilapia (Oreochromis niloticus) intestinal microbial balance, intestinal histology and growth performance. Aquaculture and Fish Nutrition Research, 344(1): 135-46.

Misra, C.K., Das, B.K., Mukherjee, S.C. and Pattnaik, P. (2006): Effect of multiple injections of $\beta$-glucan on non-specific immune response and disease resistance in Labeo rohita fingerlings. Fish \& Shellfish Immunology, 20: 305-319.

Nicholson, W.L., Munakata, N., Horneck, G., Melosh, H.J. and Setlow, P. (2000): Resistance of Bacillus endospores to extreme terrestrial and extraterrestrial environments, Microbiol. Mol. Biol. Rev., 64: 548-572.

NRC (National Research Council). (1993): Nutrient Requirements of fish. National Academy Press, Washington, DC, 112pp.

Parry, R. M., Chandan, R. C. and Shahani, K. M. (1965): A rapid and sensitive assay of muramidase. Proc Soc Exp Biol Med., 119: 383-386.

Rajaraman, V., Nonnecke, B. J., Franklin, S. T., Hammell, D. C. and Horst, R. L. (1998): Effect of vitamins A and E on nitric oxide production by blood mononuclear leukocytes from. 


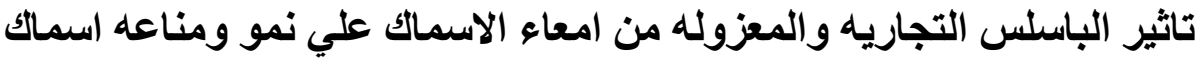

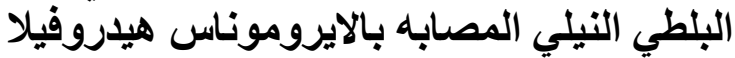

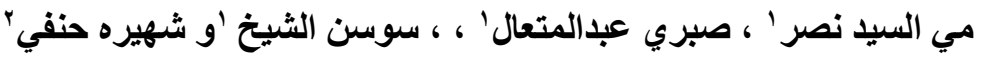

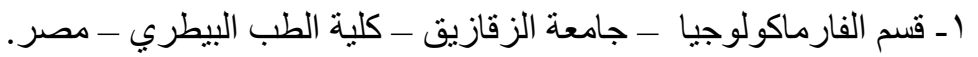

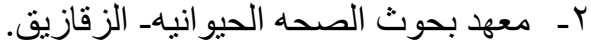

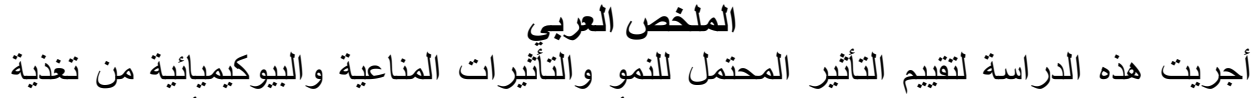

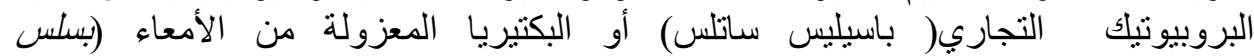
اميلوليكبوفاشنس وبسلس سيريب) ومقاومة الأمر اض في البلطي النيلي ضد عدوى الإيروموناس الإسل هبيروفيلا. أجريت هذه الدراسة على عدد ب r سمكة من أسماك البلطي النيلي قسمت إلى ؛ مجموعات

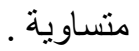
وكان تصميم التجربة على النحو التالي:-

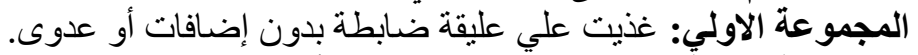

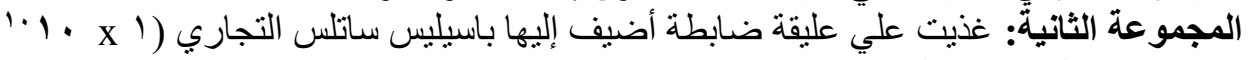

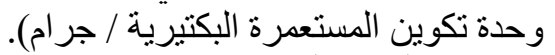

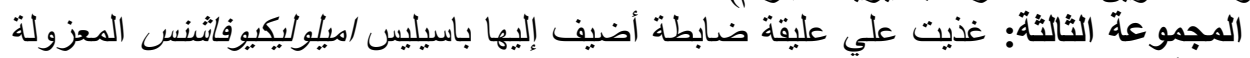

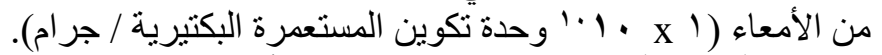

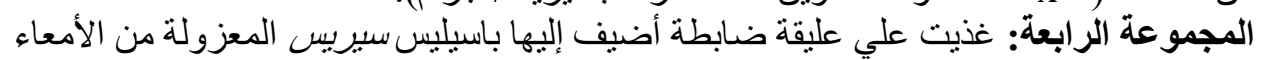

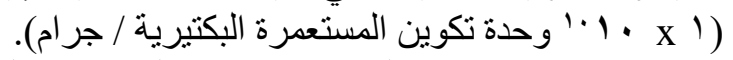

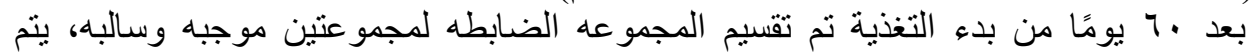

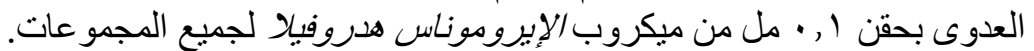

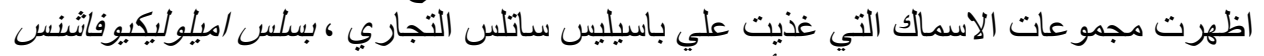

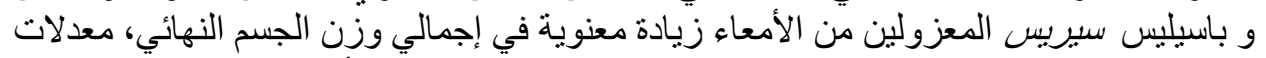

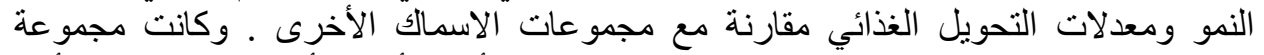

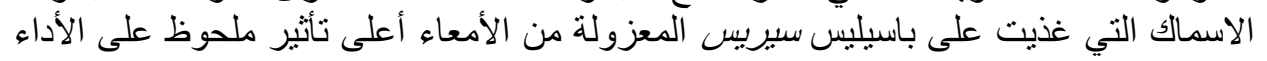
الإنتاجي بين المجمو عات المعالجة.

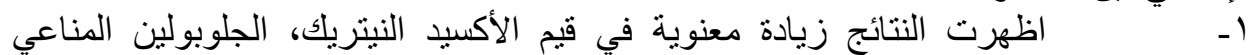

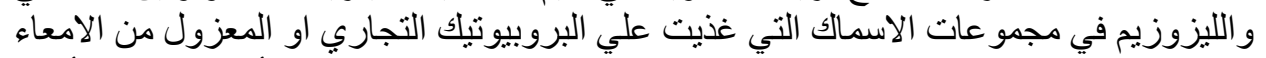

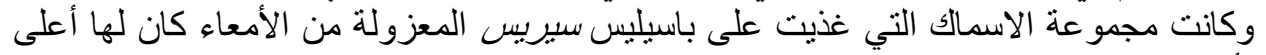

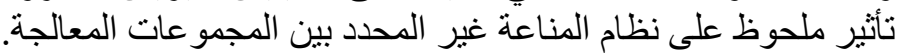

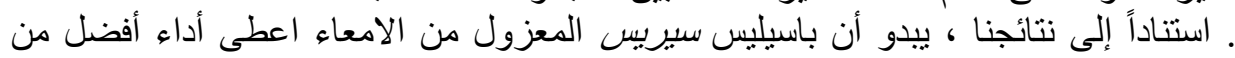

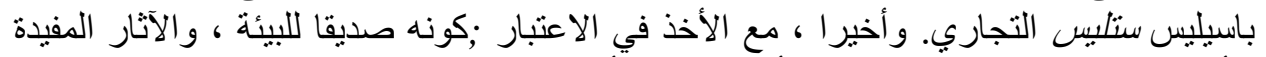

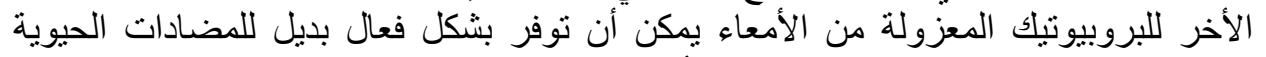
المستخدمة كمحفز نمو في صناعة وتربية الأحياء المائية. 